\title{
A new bacilliform virus in Australian Cherax destructor (Decapoda: Parastacidae) with notes on Cherax quadricarinatus bacilliform virus (= Cherax baculovirus)
}

\author{
Brett Edgerton* \\ Department of Biomedical and Tropical Veterinary Sciences, James Cook University of North Queensland, Townsville, \\ Queensland 4811, Australia
}

\begin{abstract}
Intranuclear lesions were detected in hepatopancreocytes of Cherax destructor by light microscopy. The lesions included nuclear hypertrophy, chromatin margination, a peripherally displaced nucleolus, or nucleolar remnants remaining in the centre of a granular eosinophilic inclusion. The cytoplasm of some infected cells was granular and basophilic. The intensity of the lesions was low in all cases; however, infected nuclei were sloughed from the epithelium. Rod-shaped virions within a granular viroplasm were visualised in these nuclei by electron microscopy. The virions contained a nucleocapsid, consisting of an electron-dense nucleoprotein core and less electron-dense capsid, and a trilaminar envelope. The envelope was closely applied, except that at one end it was laterally expanded to contain a tail-like structure that arose from the nucleocapsid. The nucleocapsid was often bent in this region. Capsids formed unassociated with membranes. A capsid which was partially filled with nucleoprotein was elongated and improperly enveloped. Virions were $68 \times 304 \mathrm{~nm}$ and nucleocapsids were $49 \times 263 \mathrm{~nm}$. Virions of Cherax quadricarinatus bacilliform virus consisted of a rod-shaped nucleocapsid surrounded by a loosely applied trilaminar envelope. A nucleocapsid tail-like structure was visible in several virions. Capsids appeared to form inside of membrane bubbles and capsids that were partially filled with nucleoprotein had a central filament. Virions were $103 \times 262 \mathrm{~nm}$ and nucleocapsids were $54 \times 212 \mathrm{~nm}$. The morphology and development of both viruses is compared to other arthropod bacillıform viruses.
\end{abstract}

KEY WORDS: Crayfish · Cherax destructor - Cherax quadricarinatus - Bacilliform viruses

\section{INTRODUCTION}

Even though Australia has an extremely diverse freshwater crayfish fauna (Austin 1986), only 3 species are farmed commercially. All 3 species belong to the genus Cherax. The disease status of farmed C. quadricarinatus has received considerable recent interest, and several potential pathogens have been discovered (Edgerton et al. 1995). Few potential pathogens have been described in either $C$. destructor or $C$. tenuimanus, even though extensive health surveys have recently been completed (O'Donoghue et al. 1990, L. Evans pers. comm.).

•E-mail: brett.edgerton@jcu.edu.au
Bacilliform viruses infect the gut of 3 species of freshwater crayfish. Cherax quadricarinatus bacilliform virus (CqBV) (= Cherax baculovirus) infects C. quadricarinatus in Australia (Anderson \& Prior 1992). A morphologically similar, but larger, virus also infects $C$. quadricarinatus in the USA (Groff et al. 1993). The original brood stock was imported from Australia. Astacus astacus in Finland and Pacifasticus leniusculus in the USA are also infected with bacilliform viruses (Hedrick et al. 1995, Edgerton et al. in press), however, the latter virus has not been described. Bacilliform viruses also infect the gut of other decapod crustaceans, including crabs and prawns (Johnson \& Lightner 1988).

Cherax destructor were obtained from 2 aquaculture farms in South Australia. Intranuclear inclusions were 
observed in hepatopancreocytes of some $C$. destructor by light microscopy and a new bacilliform virus was associated with these lesions by electron microscopy. The histopathology and morphology of the virus is reported here. CqBV from north Queensland crayfish was also studied by electron microscopy to further describe its morphology. Both viruses are compared to other arthropod bacilliform viruses.

\section{MATERIALS AND METHODS}

One Cherax destructor was obtained from a farm in the northwest of South Australia. Two groups of $C$. destructor, 9 in the first group and 14 in the second, were obtained from a farm in the southeast of South Australia. Ten C. quadricarinatus were obtained from a farm in north Queensland. All crayfish were adults.

The Cherax destructor from northwestern South Australia was sacrificed and fixed in Davidson's solution (Humason 1967) on site. The other 2 groups of $C$. destructor and the $C$. quadricarinatus were sacrificed immediately on arrival at the laboratory. The cephalothorax was severed from the tail and was split longitudinally. One side of the cephalothorax was placed in Davidson's solution for light microscopy and pieces of tissue were taken from the other side of the cephalothorax for electron microscopy.

Histological sections of tissues were prepared and conventionally stained with H\&E (hematoxylin and eosin) for light microscopy (Culling et al. 1985). Sections were viewed using a Leitz Orthoplan microscope. For electron microscopy, tissues were fixed in $2.5 \%$ glutaraldehyde for $3 \mathrm{~h}$, rinsed 3 times in $0.1 \mathrm{M}$ cacodylate buffer ( $\mathrm{pH} 7.4$ ) and stored at $4^{\circ} \mathrm{C}$. Tissues from animals with higher intensities of infection, as diagnosed by light microscopy, were postfixed in $1 \%$ osmium tetroxide for $1.5 \mathrm{~h}$, dehydrated through a series of ethanols and embedded in Spurrs resin. Utrathin sections were cut using a Reichert-Jung Ultracut E ultramicrotome, and were viewed using a Jeol 1010 transmission electron microscope

Virus names are in accordance with the most recent recommendations of the International Committee on Taxonomy of Viruses (Murphy et al. 1995).

\section{RESULTS}

\section{Light microscopy of Cherax destructor}

Infected nuclei were seen only in the hepatopancreatic epithelium, and were markedly hypertrophic, had marginated chromatin and contained an amorphous eosinophilic inclusion (Fig. 1). Occasionally chromatic strands compartmentalised inclusions. Basophilic nucleolar remnants usually occupied the centre of hypertrophic nuclei. The cytoplasm of infected cells often consisted of a basophilic granular material. Lytic infected cells were seen in the process of sloughing. The intensities of infection in all crayfish were low.

The lesions occurred in the animal collected from the farm in northwestern South Australia, and in 33.3\% (3/9) and $7.1 \%(1 / 14)$ of crayfish from the southeastern farm.

\section{Electron microscopy of Cherax destructor bacilliform virus ( $\mathrm{CdBV})$}

Rod-shaped virions occurred in the hypertrophied hepatopancreocyte nuclei. Nuclei had rarefied chromatin and contained an extensive granular viroplasm. Virions were scattered throughout the viroplasm and
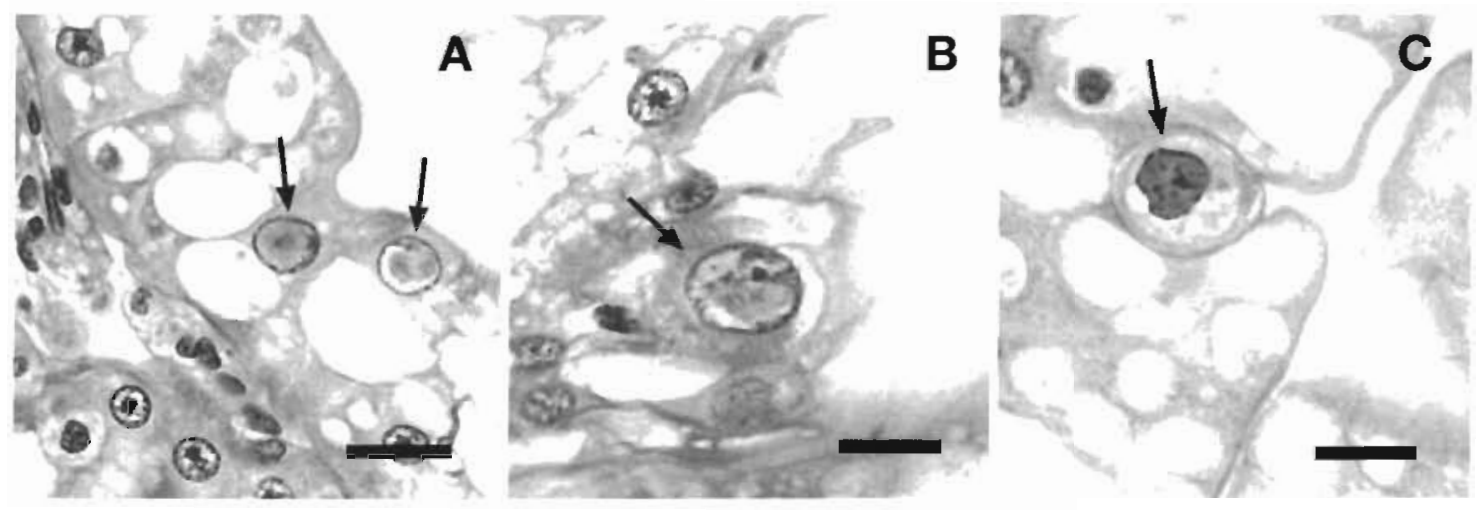

Fig. 1 Cherax destructor bacilliform virus. Light micrographs of infected hepatopancreocytes (arrows). (A) Note hypertrophy of infected nuclei, chromatin margination, nucleolar and chromatic material sometimes central in the granular inclusion. Scale bar $=25 \mu \mathrm{m}$. (B) The infected cell is detached from the basement membrane and is rounded. Scale bar $=20 \mu \mathrm{m}$. (C) The infected cell is being sloughed from the epithelium. Scale bar - 15 $\mu \mathrm{m}$. Haematoxylin and eosin 


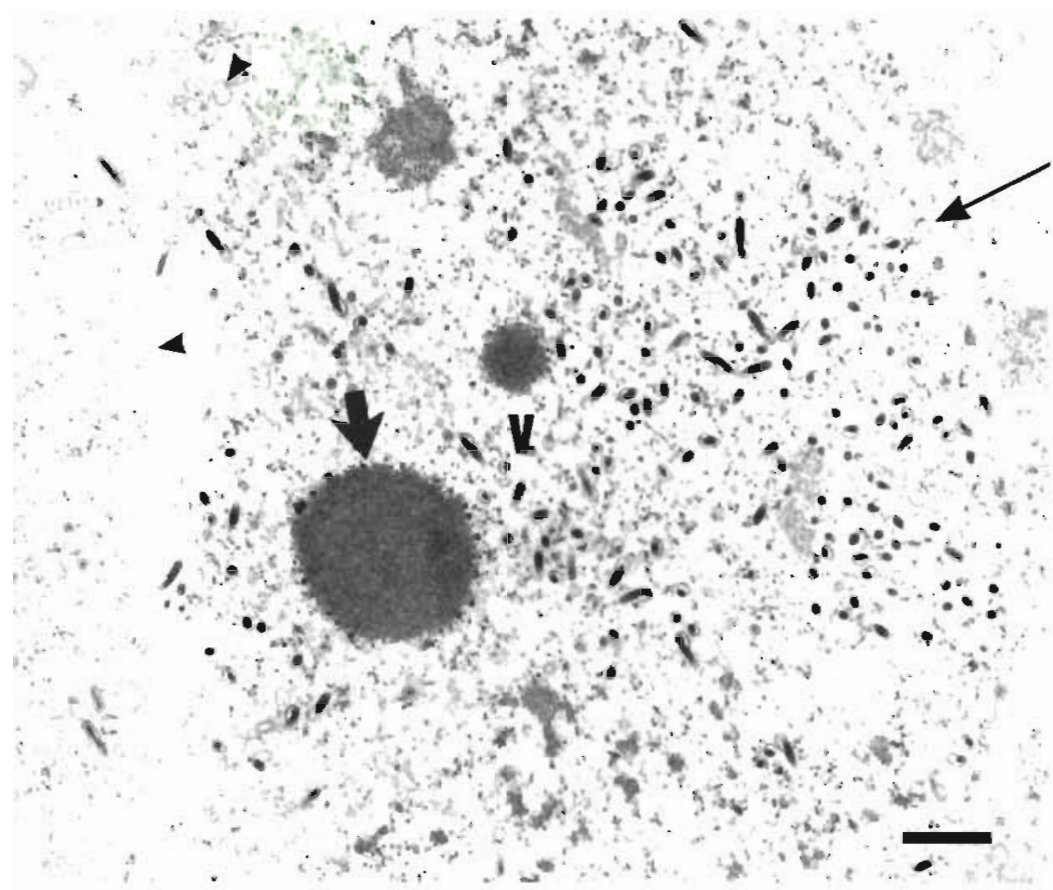

Fig. 2. Cherax destructor bacilliform virus. Rod-shaped virions scattered throughoul the viroplasm ( $V$ ) and aggregating near the inner nuclear membrane (thin arrow). Note the rounded, electron-dense putative nucleolar remnant (thick arrow) and rounded membrane fragments (arrow-heads) particularly toward the centre of the viroplasm. Scale bar $=641 \mathrm{~nm}$. Uranyl acetate and lead citrate

brane fragment covering only one end (Fig. 3b). A virion in a later stage of development was filled to approximately half its long axis with the electron-dense, nucleoprotein core, and had an envelope which completely encompassed the nucleocapsid but remained unjoined at the ends (Fig. 3c). Rounded putative nucleolar remnants occurred in infected nuclei. The cytoplasm of infected cells had abundant free ribosomes. Several cells were lytic but no virions were seen in the cytoplasm. On several occasions nucleocapsids were seen in the cytoplasm perpendicular to nuclear pores (Fig. 4). These nucleocapsids had a filament which arose from one end and was inserted through the nuclear pore into the nucleus.

Virions consisted of an electrondense core and slightly more lucent capsid, surrounded by a trilaminar envelope (Fig 5). The envelope was closely applied over one half of the virion, but was loosely applied at the other half. Virion profiles through the loose region were concentric to ec-

accumulated near the nuclear membrane in an unordered manner (Fig 2). Membrane fragments were dispersed throughout the viroplasm, and particles $29.0 \pm 1.5 \mathrm{~nm}(\mathrm{n}=5)$ in size were abundant. The membrane fragments often formed circles varying in size from the approximate diameter of a virion to much larger. The one partly formed capsid that was observed was not associated with membranes (Fig. 3a), and a fully formed but empty capsid had a short mem- centric. Longitudinally sectioned virions showed that nucleocapsids were bent in this region and the envelope, and occasionally the nucleocapsid, appeared kinked. The envelope expansion was more pronounced on one side and often visible within this expansion was a tail-like structure. The tail-like structure was attached to the nucleocapsid often via an empty cone-like structure. The tail-like structure was evident in cross-sectioned virions as a dot between the

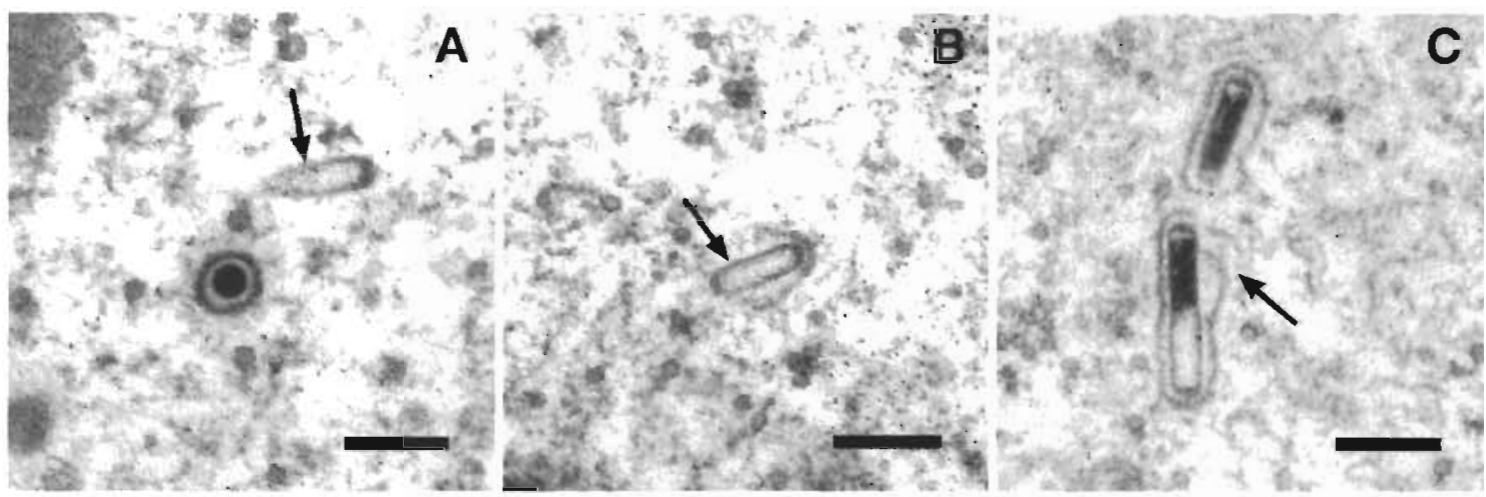

Fig. 3. Cherax destructor bacilliform virus. Presumed developmental stages. (A) Forming capsid (arrow). Scale bar $=128 \mathrm{~nm}$. (B) Fully formed capsid with a membrane fragment attached to one end (arrow). Scale bar = 154 nm. (C) Capsid partially filled with nucleoprotein. Note that the membrane fully surrounds the partially filled capsid but the ends have not joined (arrow). Scale bar $=154 \mathrm{~nm}$. Uranyl acetate and lead citrate 


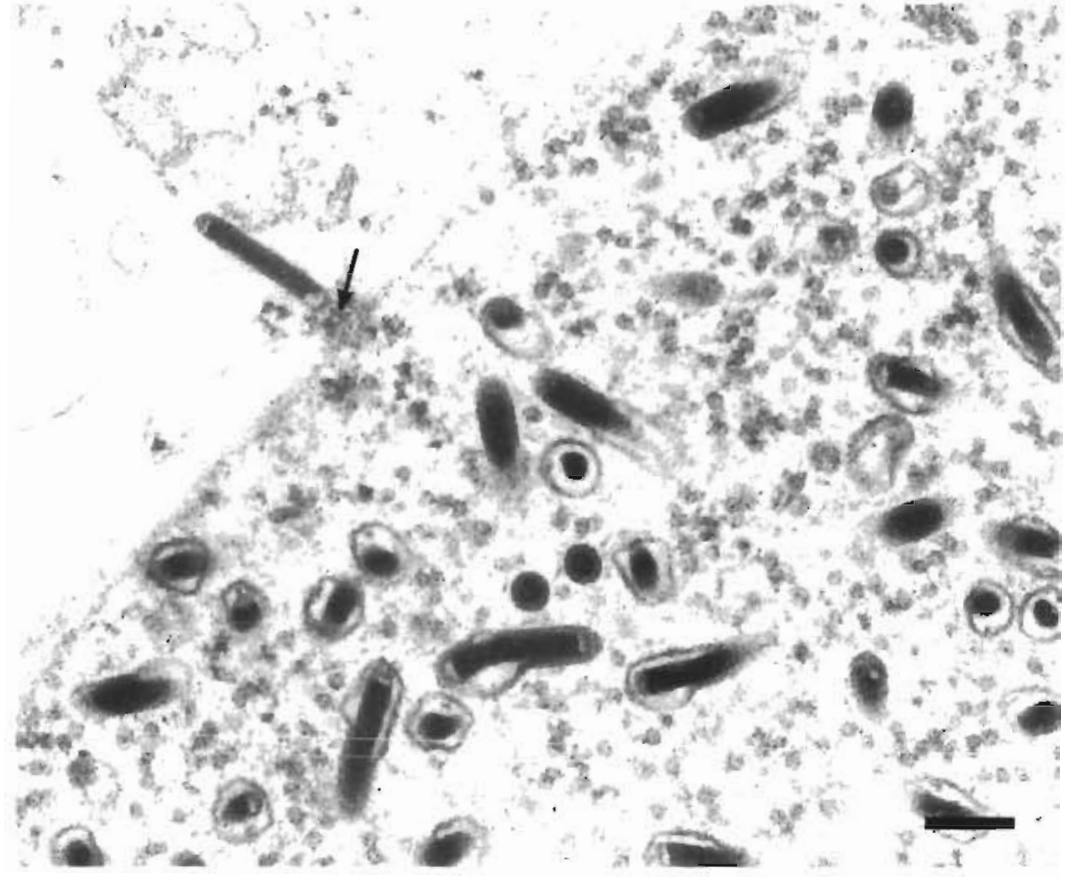

Fig 4. Cherax destructor bacilliform virus Nucleocapsid perpendicular to a nuclear pore with a tall-like structure inserted through the pore into the nucleus (arrow) The nucleus is however in a late stage of infection because fully formed virions are already in the nucleus. Note the many small round particles which are putative nbosomal precursor particles Scale bar $=154 \mathrm{~nm}$ Uranyl acetate and lead citrate

nucleocapsid and envelope. The less electron-dense capsid was markedly thicker across the ends of the nucleocapsids. Occasionally atypically long virions were seen. These virions had loosely applied envelopes, which appeared to kınk midway, but did not have true lateral envelope expansions or nucleocapsid tails

Virions were $67.7 \pm 4.9 \mathrm{~nm}(\mathrm{n}=15)$ $\times 304.4 \pm 16.2 \mathrm{~nm}(\mathrm{n}=20)$ (range $61.4-74.7 \times 271.4-330.6 \mathrm{~nm})$. Nucleocapsids were $49.3 \pm 7.0 \mathrm{~nm}(\mathrm{n}=13) \times$ $262.5 \pm 16.9 \mathrm{~nm}(\mathrm{n}=16$ ) (range $38.0-66.0$ $\times 231.2-290.3 \mathrm{~nm})$. The nucleocapsid tall was $8.7 \pm 0.5 \mathrm{~nm}(\mathrm{n}=3)$ (range 8.1-9.1 nm) in diameter. The empty capsid was $143.8 \mathrm{~nm}$, and the partially filled capsid was $258.8 \mathrm{~nm}$ in length. One atypically long virion was $415.6 \mathrm{~nm}$, and its nucleocapsid was $374.0 \mathrm{~nm}$ long

\section{Morphology of Cherax quadri- carinatus bacilliform virus (CqBV)}

Infected nuclei were hypertrophic, had marginated and rarefied chromatin and contained an extensive granular viroplasm (Fig. 6). Several rounded electron-dense putative nucleolar remnants were conspicuous in infected nuclei. The rod-shaped vinons were scattered throughout the viroplasm, accumulating at the nuclear membrane

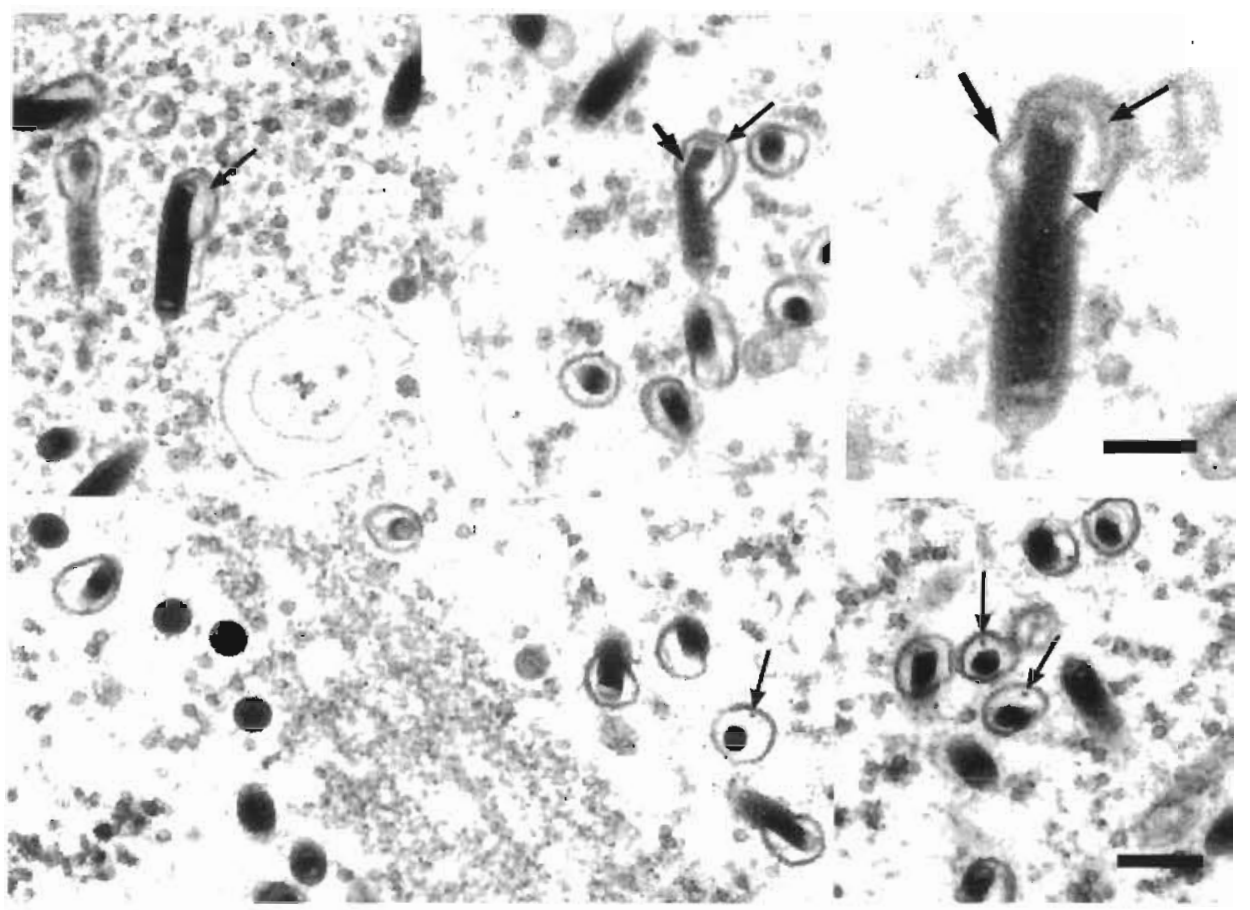

Fig. 5. Cherax destructor bacilliform virus. Collage of virions. Note the rod-shaped nucleocapsid consisting of an electron-dense core and more lucent capsid (arrow-head). A tail-like structure arises from one end (thin arrows) and the nucleocapsid is enveloped by a closely applied trilaminar envelope (long thick arrow) which is expanded at the end with the tail-Iike structure. The envelope, and sometimes the nucleocapsid (short thick arrow), is kinked when the nucleocapsid is bent. Scale bar $=1.54 \mathrm{~nm}$. (Inset) Higher magnification of a virion Scale bar $=76.9 \mathrm{~nm}$. Uranyl acetate and lead citrate 
Rounded membrane fragments approximately the diameter of enveloped virions or larger were also scattered throughout the viroplasm (Fig. 7). Empty capsids were short and were always seen within almost circular membrane bubbles (Fig. 8a). Capsids half-filled along the long axis with electron-dense nucleoprotein often had a central filament which extended from the apical cap of the capsid to the nucleoprotein (Fig. 8b). Particles of $30.6 \pm$ $1.0 \mathrm{~nm}(\mathrm{n}=6)$ were abundant throughout the viroplasm and were in close proximity to the amorphous-dense putative nucleolar remnants.

Virions consisted of a rod-shaped nucleocapsid surrounded by a loosely applied trilaminar envelope (Fig. 9). The nucleocapsid remained straight within the envelope, and consisted of an electron-dense core surrounded by a thin, less electron-dense, capsid which was thickened significantly across the apices. In a few longitudinally sectioned virions a tail-like structure arose from one end of the nucleocapsid and reflexed around to lie between the envelope and the nucleocapsid. Slight extra lateral bulging occurred in virions displaying the taillike structure. Nucleocapsids in crosssection were concentric to slightly eccentric within the envelope, and the tail-like structure was occasionally seen as a dot between the nucleocapsid and the envelope. Long tubular elements were not evident in any infected nuclei.

Virions were $102.6 \pm 5.0 \mathrm{~nm}(\mathrm{n}=20) \times$ $262.0 \pm 15.6 \mathrm{~nm}(\mathrm{n}=20)$ long (range $89.7-107.7 \times 235.9-287.2 \mathrm{~nm}$ ). Nucleocapsids were $53.5 \pm 2.8 \mathrm{~nm}(\mathrm{n}=20) \times$ $212.2 \pm 13.7 \mathrm{~nm}(\mathrm{n}=20)$ long (range $50.0-57.7 \times 194.9-232.1 \mathrm{~nm}$ ). An empty capsid was $64.1 \mathrm{~nm}$ in diameter, and an enveloped capsid was $179.5 \mathrm{~nm}$ long. The empty capsid within the envelope was $148.7 \mathrm{~nm}$ long. The halffilled capsids were 352.6 and $203.8 \mathrm{~nm}$ long including the envelope, and 294.9 and $151.3 \mathrm{~nm}$ in length excluding the envelope. The circular membranes varied in size from about 90 to $160 \mathrm{~nm}$.

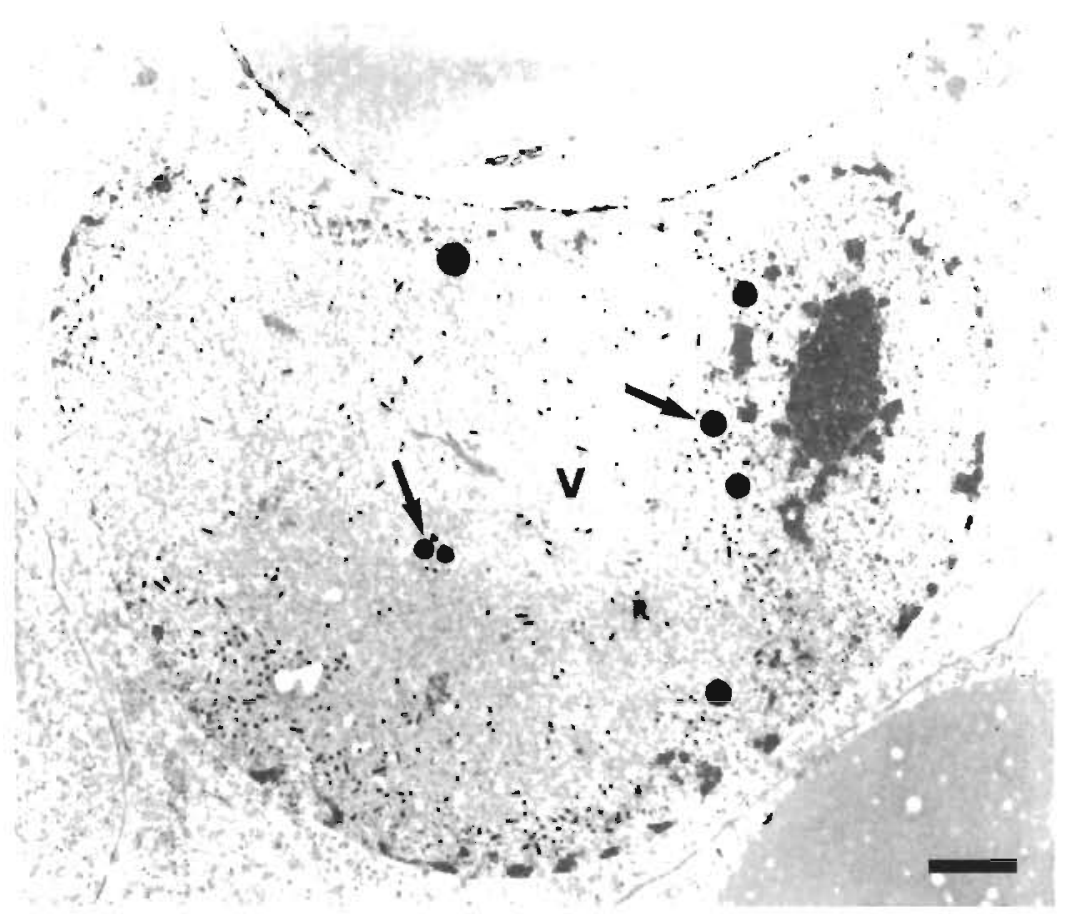

Fig. 6. Cherax quadricarinatus baclliform virus. Infected hepatopancreocyte nucleus. Note multiple electron-dense round putative nucleolar remnants (arrows) and cod-shaped virions scattered throughout the viroplasm (V). Scale bar $=1.56 \mu \mathrm{m}$. Uranyl acetate and lead citrate

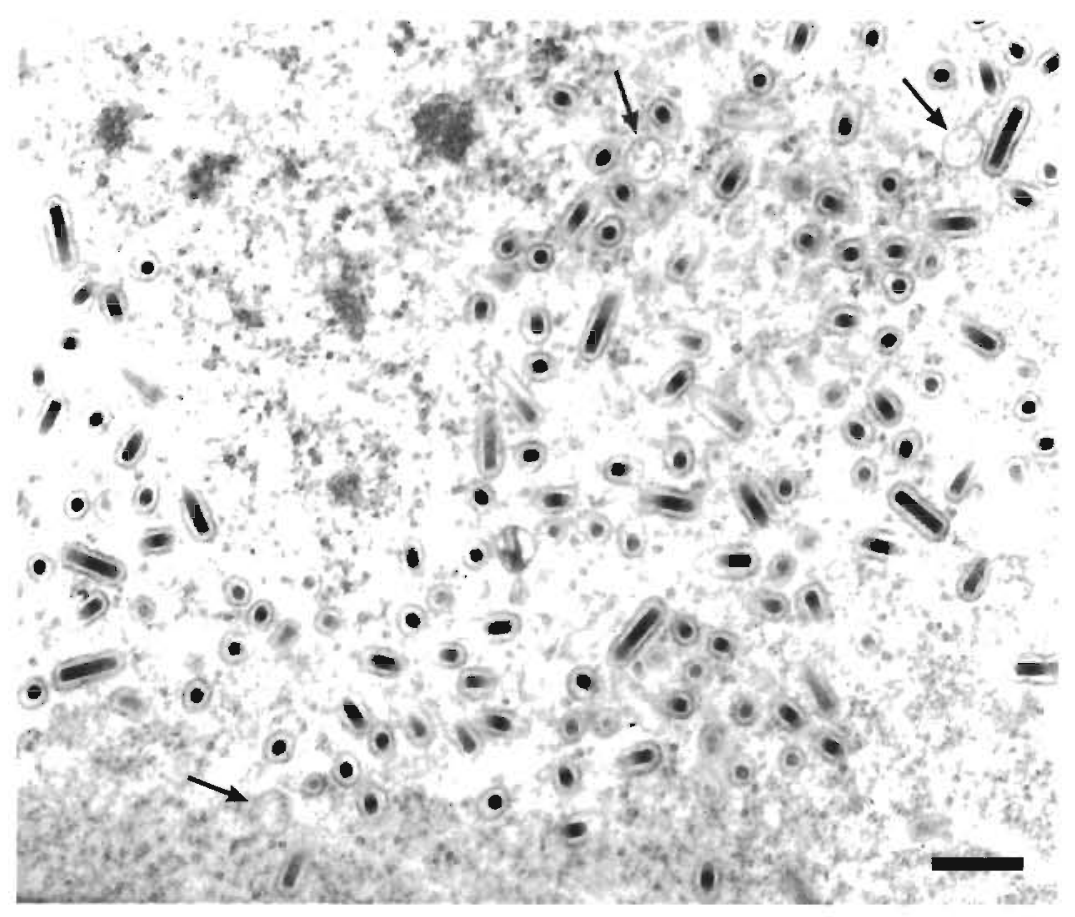

Fig. 7. Cherax quadricarinatus bacilliform virus. Fully formed virions and some round membrane bubbles (arrows) which approximate the size or are a little larger than cross-sectioned virions. Note that the envelopes of fully formed virions are loosely applied and note also the putative ribosomal precursor particles. Scale bar $=313 \mathrm{~nm}$. Uranyl acetate and lead citrate 


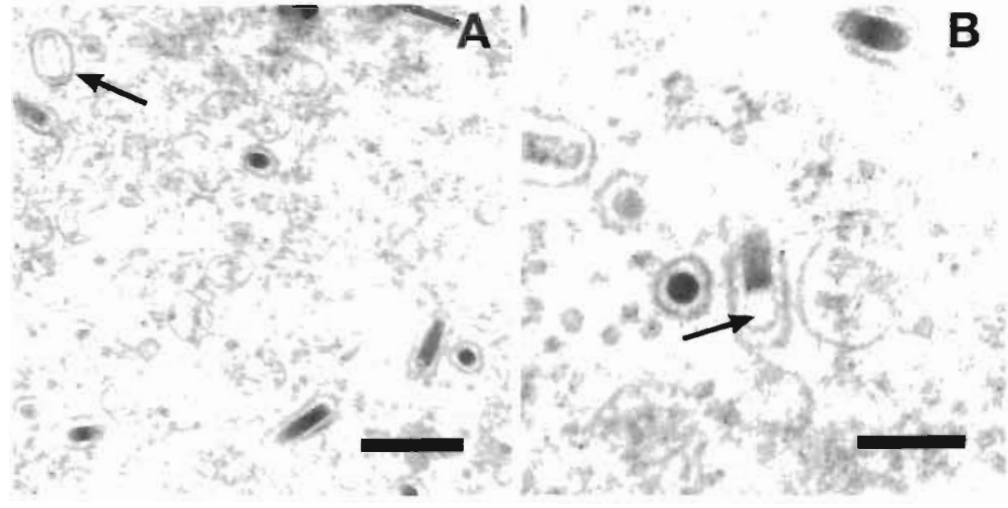

Fig. 8. Cherax quadricarinatus bacilliform virus. Presumed developmental stages. (A) Rounded membrane fragments and bubbles. A capsid has formed in one bubble (arrow). Scale bar $=313 \mathrm{~nm}$. (B) A capsid partially filled with nucleoprotein. Note that a thin filament extends from the nucleoprotein to the unfilled end of the capsid (arrow). Scale bar $=154 \mathrm{~nm}$. Uranyl acetate and lead citrate

\section{DISCUSSION}

Whilst Cherax destructor from South Australia have previously been surveyed for disease (O'Donoghue et al. 1990 ), this is the first description of a virus from this species. Those authors concentrated mainly on parasites and histology was used minimally. This approach therefore precluded the possibility of diagnosing viral infections.
Recently, the subfamily Nudibaculovirinae (Francki et al. 1991) of the family Baculoviridae, which comprised nonoccluded baculoviruses, was dissolved (Murphy et al. 1995). The Oryctes rhinoceros virus and the Heliothis zea virus 1 , the best studied members of the group, are now unclassified viruses. Of the crustacean bacilliform viruses, only Penaeus monodon nucleopolyhedrovirus (PmSNPV) and Penaeus duorarum nucleopolyhedrovirus (PdSNPV) are considered possible members of the Baculoviridae because they form proteinaceous inclusion bodies.

CdBV is similar to other crustacean gutinfecting bacilliform viruses (Table 1). CdBV nucleocapsids are true cylinders like all of the crustacean gut-infecting bacilliform viruses. The much thicker apical caps of CdBV and CqBV capsids observed in thin section were like those in the Astacus astacus bacilliform virus (AaBV) (Edgerton et al. in press). Apical nucleocapsid caps have also been reported for PdSNPV, Tau, baculoviral midgut gland necrosis virus (BMNV) (Johnson \& Lightner 1988), and PmSNPV (Mari et al. 1993), but only after negative staining. CdBV has a tightly applied envelope. CqBV and PdSNPV are unusual amongst the crustacean gut-

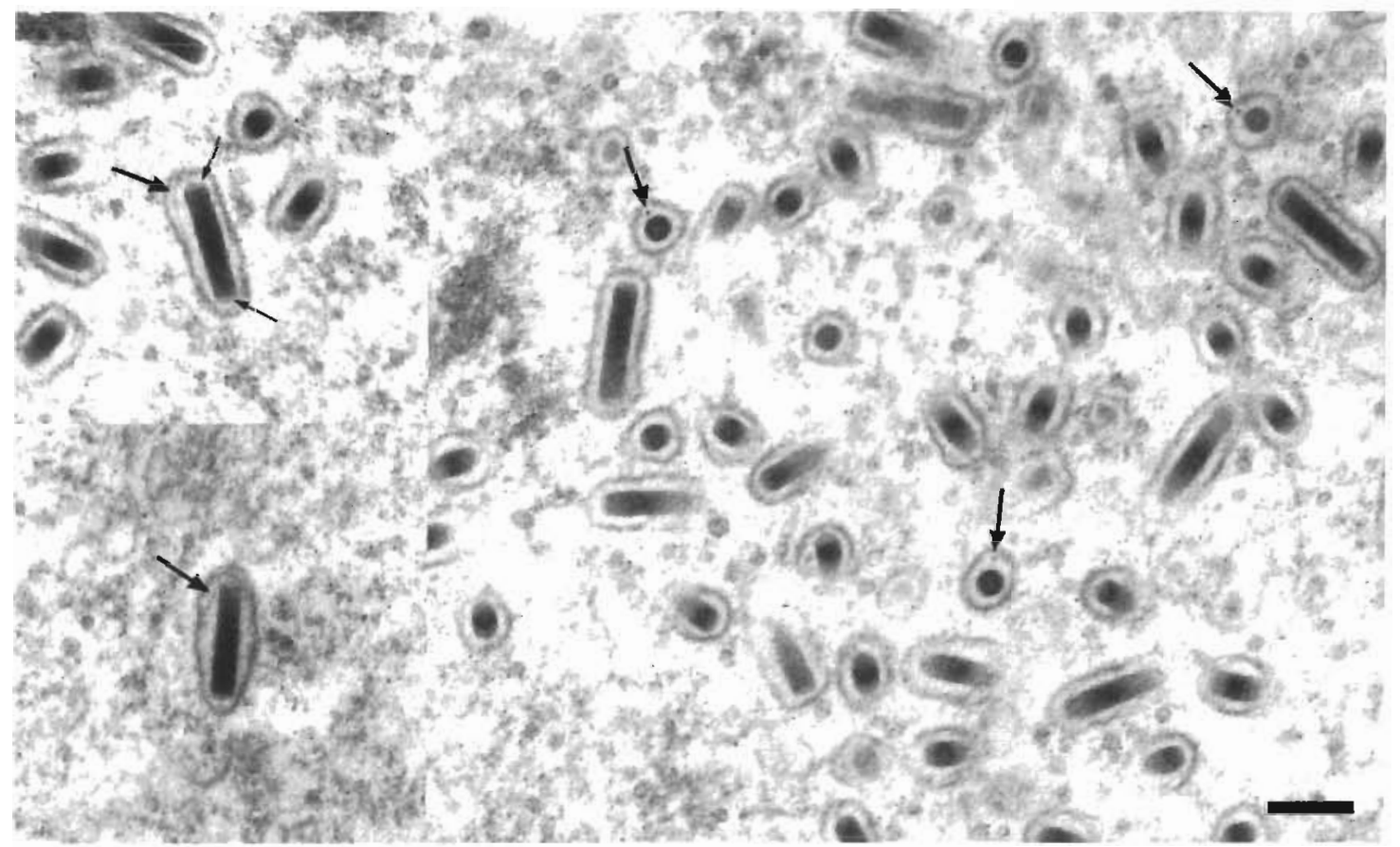

Fig. 9. Cherax quadricarinatus bacilliform virus. Collage of virions. Note the rod-shayed nucleocapsid with a tall-like structure (appears as a dot in cross-section) (large arrows), and the thicker aplcal caps of the capsid (small arrows). Scale bar $=154 \mathrm{~nm}$. Uranyl acetate and lead citrate 
Table 1. Characteristics of the crustacean gut-infecting bacilliform viruses (BV) (adapted from Johnson \& Lightner 1988). PIBV Pacifasticus leniusculus bacilliform virus. Other definitions of virus names given in 'Discussion. AM: anterior midgut; H: hepatopancreas; MG: midgut; MGC: midgut caecum; TG: tegmental gland; FW: freshwater; SW: saltwater; "negatively stained preparation. Note: All viruses - (1) have nucleocapsids which are true cylinders, (2) except for PmSNPV and PdSNPV, are not occluded withın a protein body, and (3) for which there is information, do not have unenveloped nucleocapsids

\begin{tabular}{|c|c|c|c|c|c|c|c|c|}
\hline Virus & $\begin{array}{l}\text { Host } \\
\text { (environment) }\end{array}$ & $\begin{array}{l}\text { Tissue } \\
\text { infected }\end{array}$ & $\begin{array}{l}\text { Nucleo- } \\
\text { capsid } \\
\text { size } \\
\text { (nm) }\end{array}$ & $\begin{array}{l}\text { Envelope } \\
\text { modifica- } \\
\text { tions/nucleo- } \\
\text { capsid tail }\end{array}$ & $\begin{array}{l}\text { Develop- } \\
\text { ment with } \\
\text { mem- } \\
\text { branes }\end{array}$ & $\begin{array}{l}\text { Loose } \\
\text { enve- } \\
\text { lope }\end{array}$ & $\begin{array}{l}\text { Cytoplasmic } \\
\text { virions } \\
\text { (untact } \\
\text { nucleus) }\end{array}$ & Source \\
\hline $\mathrm{CqBV}$ & $\begin{array}{l}\text { Cherax } \\
\text { quadricarinatus } \\
(\mathrm{FW})\end{array}$ & $\mathrm{H} \& \mathrm{MG}$ & $\begin{array}{r}34 \times 154 \\
-50 \times 215\end{array}$ & Yes/Yes & Yes & Yes & No & $\begin{array}{l}\text { Anderson \& Prior } 1992 . \\
\text { Groff et al. 1993, } \\
\text { Edgerton et al. 1995, } \\
\text { This report }\end{array}$ \\
\hline CdBV & $\begin{array}{l}\text { Cherax } \\
\text { destructor }(\mathrm{FW})\end{array}$ & $\mathrm{H}$ & $49 \times 262$ & Yes/Yes & No & No & No & This report \\
\hline PIBV & $\begin{array}{l}\text { Pacifasticus } \\
\text { leniusculus (FW) }\end{array}$ & $\mathrm{H}$ & $44 \times 189$ & $?$ & $?$ & $?$ & $?$ & Hedrick et al. 1995 \\
\hline $\mathrm{AaBV}$ & $\begin{array}{l}\text { Astacus } \\
\text { astacus (FW) }\end{array}$ & $\begin{array}{c}\mathrm{H}, \mathrm{MG} \\
\mathrm{MGC} \& \mathrm{IG}\end{array}$ & $51 \times 261$ & Yes/Yes & No & No & No & Edgerton et al. in press \\
\hline BMNV & $\begin{array}{l}\text { Penaeus } \\
\text { japonicus (SW) }\end{array}$ & $\mathrm{H}$ & $36 \times 250$ & Yes/Yes & No & No & $?$ & Sano et al. 1981, 1984 \\
\hline Tau & $\begin{array}{l}\text { Carcinus medit- } \\
\text { teraneus (SW) }\end{array}$ & $\mathrm{H} \& \mathrm{MG}$ & $68 \times 310^{\circ}$ & Yes/Yes & No & No & Yes & $\begin{array}{l}\text { Pappalardo \& Bonami } \\
1979\end{array}$ \\
\hline Baculo-A & $\begin{array}{l}\text { Callinectes } \\
\text { sapidus (SW) }\end{array}$ & $\mathrm{H}$ & $43 \times 247$ & Yes/? & $?$ & No & $?$ & $\begin{array}{l}\text { Johnson \& Lightner } \\
1988\end{array}$ \\
\hline Baculo-PP & $\begin{array}{l}\text { Parolithodes } \\
\text { platypus (SW) }\end{array}$ & $\mathrm{H}$ & $38 \times 200$ & Yes/Yes & $?$ & No & $?$ & $\begin{array}{l}\text { Johnson \& Lightner } \\
1988\end{array}$ \\
\hline SsBV & Scylla serata (SW) & $\mathrm{H}$ & $24 \times 205$ & Yes/Yes & No & No & Yes & Anderson \& Prior 1992 \\
\hline PmSNPV & $\begin{array}{l}\text { Penaeid prawns } \\
\text { (SW) }\end{array}$ & $\mathrm{H} \& \mathrm{AM}$ & $42 \times 246$ & Yes/Yes & Yes & No & No & $\begin{array}{l}\text { Johnson \& Lightner } \\
1988\end{array}$ \\
\hline PdSNPV & $\begin{array}{l}\text { Penaeus } \\
\text { duorarum (SW) }\end{array}$ & $\mathrm{H} \& \mathrm{AM}$ & $50 \times 270$ & Yes/Yes & Yes & Yes & Yes & $\begin{array}{l}\text { Couch 1974, Johnson \& } \\
\text { Lightner } 1988\end{array}$ \\
\hline
\end{tabular}

infecting bacilliform viruses because they have loosely applied envelopes. The bending of the CdBV nucleocapsid is unique amongst the freshwater crayfish bacilliform viruses. Bending of the nucleocapsid is a significant feature of some Tau virus preparations (Pappalardo et al. 1986) and also occurs in BMNV (Sano et al. 1981, 1984) and PmSNPV (Johnson \& Lightner 1988).

A nucleocapsid tail was clearly seen in CdBV and CqBV. This is the first time the nucleocapsid tail has been reported in CqBV. Groff et al. (1993) did however describe a lateral 'cup handle-like' protrusion of the envelope at one end, and the tail can be seen in both longitudinal and transverse virion sections in that publication (Fig. 2). Most crustacean gut-infecting bacilliform viruses have tail-like structures (Johnson \& Lightner 1988). Systemic ectodermal and mesodermal baculovirus (SEMBV) is the only other crustaceaninfecting bacilliform virus which has this structure (Wongteerasupaya et al. 1995); notably, the other crustacean haemocyte-infecting bacilliform viruses do not have nucleocapsid tails. Oryctes rhinoceros virus (Payne et al. 1977), Mesoleius tenthridinis bacilliform virus (Stoltz 1981), Chaoborus crystallinus bacilliform virus (Larsson 1984), and polydnaviruses (Stoltz \& Vinson 1979) also have nucleocapsid tails.

Full nucleocapsids of CdBV were perpendicular to the nuclear membrane with a filament inserted through the nuclear pore. Nucleocapsids of PmSNPV (Johnson \& Lightner 1988), PdSNPV (Couch 1991), and the occluded insect baculovirus Trichoplusia ni granulovirus (Summers 1971) have also been reported to be in such an alignment, as have the bacilliform viruses in Mesoleius tenthridinis (Stoltz 1981) and Microplitis croceipes (Hamm et al. 1992), and the polydnaviruses (Stoltz \& Vinson 1979). These nucleocapsids are presumably in the process of uncoating following entry into the cell by fusion of the viral envelope with the plasma membrane, explaining the lack of envelope, or by some other method (Johnson \& Lightner 1988, Couch 1991, Hamm et al. 1992). Couch (1991) believed that the filament was of DNA. The CdBV filament inserted into the nucleus was similar in size to the taillike structures seen in fully formed CdBV. The tail-like structure may therefore be a filamentous extension of the viral genome, or it may serve as a conduit for the 
entry of viral DNA into the nucleus. In the present study, and that by Johnson \& Lightner (1988), nucleocapsids in this position were observed by chance whilst studying nuclei already in a late stage of infection.

CdBV and CqBV virion formation appeared to be subtly different. In CdBV, the first developmental stage observed was a partly formed capsid. The development of the capsid occurred without membranes; however, a membrane attached to one end of the capsid once it was complete. The nucleoprotein was then inserted into the capsid from one end forward; however, how this occurred was not apparent. The capsid elongated during this process. The membrane fully surrounded the forming nucleocapsid but did not envelope it. No stages were seen between this stage and complete virions. CqBV capsids on the other hand appeared to develop in close association with membranes, probably internally in membrane bubbles. The nucleoprotein core again filled from one end forward. The nucleoprotein may have been inserted along a fine filament which was seen in one developing virion. The capsid elongated whilst filling with nucleoprotein.

The association of membranes with developing virions is inconsistent amongst the crustacean bacilliform viruses. Amongst the crayfish bacilliform viruses, CqBV develops in association with membranes, and CdBV and AaBV do not (Edgerton et al. in press). Furthermore, the membrane bubbles in which $\mathrm{CqBV}$ virions apparently form may be equivalent to the capsid originators of PdSNPV (Johnson \& Lightner 1988) and the crustacean haemocyte-infecting bacilliform viruses (Johnson 1988). Although similarly sized round membrane structures were seen in CdBV infected nuclei, an unenveloped capsid was seen and a forming nucleocapsid was not properly enveloped. The first and only stage of AaBV virion formation documented by Edgerton et al. (in press) was fully enveloped capsids. BMNV and Tau virions develop in the absence of membranes; however, Tau may also develop in association with membranes (Johnson \& Lightner 1988). PmSNPV virions develop in association with membranes, and naked capsids do not occur in infected nuclei. Oryctes rhinoceros virus can develop with and without membranes (Huger 1966, Crawford \& Sheehan 1985), and the Chaoborus crystallinus (Larsson 1984) and Gyrinus natator (Gouranton 1972) bacilliform viruses develop in association with membranes. Both the bracoviruses and ichnoviruses of the Polydnaviridae also develop in association with membranes (Stoltz \& Vinson 1979).

Johnson \& Lightner (1988) postulated that the nucleoprotein enters the capsid along a filament which runs through the centre of the capsid longitudinally. This filament has been visualised in most crustacean gutand haemocyte-infecting bacilliform viruses, and in
Oryctes rhinoceros virus (Johnson \& Lightner 1988). Of the freshwater crayfish bacilliform viruses, only CqBV has been definitely shown to contain this filament (this report). Only one $\mathrm{CdBV}$ virion, and no $\mathrm{AaBV}$ virions (Edgerton et al. in press), were seen in the process of being filled with nucleoprotein, and it is therefore possible that such structures will be visualised in these viruses with further study.

Putative ribosomal precursor particles are a consistent pathological feature of freshwater crayfish bacilliform viruses as well as BMNV (Sano et al. 1981), PmSNPV, and Baculo-A (Johnson \& Lightner 1988) and also the Bacillus rossius bacilliform virus (Scali et al. 1980). Unlike with PmSNPV and Baculo-A (Johnson \& Lightner 1988), however, the particles were never arranged around virions of CdBV or CqBV at a fixed distance. Such a formation did not occur in AaBV either (Edgerton unpubl.). In $\mathrm{CqBV}$, the particles were often at the periphery of the very dense round nucleolar bodies, suggesting that they were either emitted from the structures, or fused with them. The particles also accumulated into less electron-dense, irregularly shaped bodies.

Virions were not seen in the cytoplasm of cells infected with CdBV or CqBV. Virions were only seen in the cytoplasm of lytic cells infected with AaBV (Edgerton et al. in press). Freshwater crayfish bacilliform viruses therefore probably rely on lysis and cellular sloughing for cell to cell transmission. PdSNPV, the 2 crab gut-infecting bacilliform viruses Tau and Scylla serrata bacilliform virus (SsBV), and many of the insect bacilliform viruses are however capable of budding through the nuclear membrane (Huger 1966, Bird 1967, Reed \& Hall 1972, Couch 1974, Avery et al. 1977, Kitajima et al. 1978, Stoltz 1981, Kim \& Kitajima 1984, Pappalardo et al. 1986, Anderson \& Prior 1992, Hamm et al. 1992).

The measurements of CqBV in this study are very similar to those obtained by Groff et al. (1993) in Cherax quadricarinatus in the USA, and are considerably larger than those reported by Anderson \& Prior (1992). This inconsistency may be wholly or partly due to the method of fixation. Tissues for electron microscopy in the present study and that done by Groff et al. (1993) were fixed in 2.5\% glutaraldehyde. Anderson \& Prior (1992) fixed tissues for both light and electron microscopy in $10 \%$ neutral buffered formalin. The very round and electron-dense nucleolar remnants were a prominent feature of the pathology described by Anderson \& Prior (1992) and also this report. The long tubular structures reported by Anderson \& Prior (1992) were not seen in the present study and were not reported by Groff et al. (1993). The latter report, however, did not concentrate on the electron microscopic pathology of the virus. The morphological similarity of 
the C. quadricarinatus bacilliform viruses suggest that they are the same virus. However, considerable racial variation occurs in C. quadricarinatus (Austin 1986), and the species may consist of as many as 12 different strains (Hutchings 1987). It is therefore possible that there are also several strains of $\mathrm{CqBV}$

CdBV has an envelope which is tightly applied except at the end which is bent and contains the nucleocapsid tail. CqBV, the only other bacilliform virus found in an Australian freshwater crayfish, has a loosely applied envelope. AaBV has a closely applied envelope, again except at the end with the nucleocapsid tail (Edgerton et al. in press). In AaBV, however, the envelope expansion only occurs on the side in which the tail is reflexed and the nucleocapsid remains straight. CdBV therefore has unique characteristics and should therefore be considered as a new species. The finding of a new bacilliform virus in Cherax destructor has further broadened the host range of these viruses, and viruses in general, in freshwater crayfish. A histopathological survey of farmed C. destructor would be helpful in identifying whether CdBV, or any other virus or microorganism, potentially threatens this industry.

Johnson \& Lightner (1988) suggested that occlusion of crustacean gut-infecting bacilliform viruses within protein bodies is not important in their taxonomy. The information emerging about the freshwater crayfish viruses supports this. The morphology of all crustacean gut-infecting bacilliform viruses is very similar; however, there may be a divergence in morphogenesis. As an example, CqBV shares many developmental and morphological characteristics with the occluded prawn virus PdSNPV The non-gut-infecting crustacean bacilliform viruses differ both morphologically and developmentally. The present concentration of research effort on purifying and characterising crustacean bacilliform viruses will add to our understanding of the relatedness of these viruses and therefore to their taxonomy. Further, the conclusions of Johnson \& Lightner (1988), this author considers that crustacean gutinfecting bacilliform viruses should be considered closely related if the only significant difference between the occluded and non-occluded viruses is the occurrence of polyhedrin gene sequences in their genomes.

Acknowledgements. The collection of samples by Mr Max Wingfield of the Department of Primary Industries South Australia is gratefully appreciated. The electron microscopy in this report was performed at the Centre for Microscopy and Microanalysis at the University of Queensland and I therefore thank the staff of the that centre for their help. In particular I appreciate the excellent technical assistance and advice of Mr Rick Webb. Dr Robert Coelen of the Department of Biomedical and Tropical Veterinary Sciences at James Cook Uni- versity, and Prof. John McKenzie of the Department of Microbiology at University of Queensland, are sincerely thanked for their contributions. Dr Leigh Owens of the Department of Biomedical and Tropical Veterinary Sciences at James Cook University is thanked for his continued support and for editing the manuscript. This research was supported by the Australian Research Council grant number A19332302.

\section{LITERATURE C:TED}

Anderson IG, Prior HC (1992) Baculovirus infections in the mud crab, Scylla serrata, and a freshwater crayfish, Cherax quadricarinatus, from Australia. J Invertebr Pathol 60:265-273

Austin C (1986) Genetic considerations in freshwater crayfish farming. In Owen P, Bowden J (eds) Aquaculture in Australia. Fish farming for profit. Rural Press, Brisbane, p 73-78

Avery SW, Jouvenaz DP, Banks WA, Anthony DW (1977) Virus-like particles in a fire ant, Solenopsis sp., (Hymenoptera: Formicidae) from Brazil. Fla Entomol 60:17-20

Bird FT (1967) A virus disease of the European red mite Panonychus ulmi (Koch). Can J Microbiol 13:1131

Couch JA (1974) An enzootic nuclear polyhedrosis virus of pink shrimp: ultrastructure, prevalence, and enhancement. J Invertebr Pathol 24:311-331

Couch JA (1991) Baculoviridae. Nuclear polydrosis viruses Part 2. Nuclear polyhedrosis viruses of invertebrates other than insects. In: Adams JR, Bonami JR (eds) Atlas of invertebrate viruses. CRC Press, Boca Raton, p 295-326

Crawford AM, Sheehan C (1985) Replication of Oryctes baculovirus in cell culture: viral morphogenesis, infectivity and protein synthesis. J Gen Virol 66:529-539

Culling CFA, Allison RT, Barr WT (1985) Cellular pathology techniques, 4 th edn. Butterworths, London

Edgerton B, Owens L, Harris L, Thomas A, Wingfield M (1995) A health survey of farmed redclaw crayfish Cherax quadricarinatus (von Martens). in tropical Australia. Freshwater Crayfish 10:322-338

Francki RIB, Fauquet CM, Knudsen DL, Brown F (1991) Classification and nomenclature of viruses. Arch Virol Suppl 2:1-450

Gouranton J (1972) Development of an intranuclear nonoccluded rod-shaped virus in some midgut cells of an adult insect, Gyrinus natator L. (Coleoptera). J Ultrastruct Res 39:281-294

Groff JM, McDowell T, Friedman, CS, Hedrick RP (1993) Detection of a non-occluded baculovirus in the freshwater crayfish Cherax quadricarinatus in North America. J Aquat Anim Health 5:275-279

Hamm JJ, Styer EL, Lewis WJ (1992) Three viruses found in the braconid parasitoid Microplitis croceipes and their implications in biological control programs. Biol Control $2: 329-336$

Hedrick RP, McDowell TS, Friedman CS (1995) Baculoviruses found in two species of crayfish from California. Aquaculture '95 (Abstracts): 135

Huger AM (1966) A virus disease of the Indian rhinoceros beetle, Oryctes rhinoceros (Linnaeus), caused by a new type of insect virus, Rhabdionvirus oryctes gen. n., sp. n. J Invertebr Pathol 8:38-51

Humason GL (1967) Animal tissue techniques. WH Greeman Co., San Francisco

Hutchings R (1987) Exciting new crayfish. Austasia Aquac Mag 1(12):12-13 
Johnson PT (1988) Rod-shaped nuclear viruses of crustaceans: hemocyte-infecting species. Dis Aquat Org 5:111-122

Johnson PT, Lightner DV (1988) Rod-shaped nuclear viruses of crustaceans: gut-infecting species. Dis Aquat Org 5 : $123-141$

Kim KS, Kitajima EW (1984) Nonoccluded baculovirus- and filamentous virus-like particles in the spotted cucumber beetle, Diabrotica undecimpunctata (Coleoptera: Chrysomelid). J Invertebr Pathol 43:234-241

Kitajima EW, Costa CL, Sá CM (1978) Baculovirus-like particles in two aphid species. J Invertebr Pathol 31:123-125

Larsson R (1984) Baculovirus-like particles in the midgut epithelium of the phantom midge, Chaoborus crystallinus (Diptera, Chaoboridae). J Invertebr Pathol 44:178-186

Mari J, Bonami JR, Poulos B, Lightner D (1993) Preliminary characterization and partial cloning of the genome of a baculovirus from Penaeus monodon (PmSNPV=MBV). Dis Aquat Org 16:207-215

Murphy FA, Fauquet CM, Mayo MA, Jarvis AW, Ghabrial SA. Summers MD, Martelli GP, Bishop DHL (1995) The classification and nomenclature of viruses: sixth report of the International Committee on Taxonomy of Viruses. Archives of Virology, Springer Verlag, Wien

O'Donoghue P, Beveridge I, Phillips P (1990) Parasites and ectocommensals of yabbies and marron in South Australia. Central Veterinary Laboratories (Vetlab), South Australian Department of Agriculture, Adelaide

Pappalardo R, Bonami JR (1979) Infection des Crustacés marines due à un virus de type nouveau apparenté aux Baculovirus. C R Acad Sci (Ser D)288:535-537

Pappalardo R, Mari J, Bonami JR (1986) $\tau$ (tau) virus infection of Carcinus mediterraneus: histology, cytopathology, and experimental transmission of the disease. J Invertebr

Responsible Subject Editor: J. E. Stewart, Dartmouth, Nova Scotia, Canada
Pathol 47:361-368

Payne CC, Compson D, de Looze SM (1977) Properties of the nucleocapsids of a virus isolated from Oryctes rhinoceros. Virology 77:269-280

Reed DK, Hall IM (1972) Electron microscopy of a rod-shaped noninclusion virus infecting the citrus red mite. J Invertebr Pathol 20:272-278

Sano T, Nishimura T, Oguma K, Momovama K, Takeno N (1981) Baculovirus infection of cultured Kuruma shrimp, Penaeus japonicus, in Japan. Fish Pathol 15(3/4):185-191

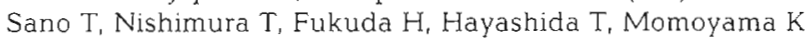
(1984) Baculoviral mid-gut gland necrosis (BMN) of kuruma shrimp (Pendeus japonicus) larvae in Japanese intensive culture systems. Helgol Meeresunters 37: 255-264

Scali V, Montanelli E, Lanfranchi A, Bedini D (1980) Nuclear alterations in a baculovirus-like infection of midgut epithelial cells in the stick insect Bacillus rossius. J Invertebr Pathol 35:109-118

Stoltz DB (1981) A putative baculovirus in the ichneumonid parasitoid, Mesoleius tenthredinis. Can J Microbiol 27(1): $116-122$

Stoltz DB, Vinson SB (1979) Viruses and parasitism in insects. Adv Virus Res 24:125-171

Summers MD (1971) Electron microscopic observations on granulosis virus entry, uncoating and replication during infection of the midgut cells of Trichoplusia ni. J Ultrastruct Res 35:606-625

Wongteerasupaya C, Vickers JE, Sriurairatana S, Nash GL, Akarajamorn A, Boonsaeng V, Panyim S, Tassanakajon, Withyachumnarnkul B, Flegel TW (1995) A non-occluded. systemic baculovirus that occurs in cells of ectodermal and mesodermal origin and causes high mortality in the black tiger prawn Penaeus monodon. Dis Aquat Org 21:29-77

Maruscript first received: January 16, 1996

Revised version accepted: June 26, 1996 